\title{
Cellulase activity of Aspergillus niger in the biodegradation of rice husk
}

\begin{abstract}
Rice husk, a major waste product of rice milling factory in Nigeria, was hydrolyzed by cellulolytic enzymes of Aspergillus niger. Aspergillus niger synthesizes cellulase which biodegrade the cellulose content of rice husk. The cellulase activity was measured by the release of reducing sugar over the period of biodegradation. The reducing sugar content of the biodegraded rice husk showed a significant increase with an increase in days of biodegradation $(0.560-1.020 \mathrm{mg} / \mathrm{ml}$ from day zero through day five, to day nine). The maximum yield of glucose concentration was observed on day five of biodegradation at $\mathrm{pH}$ of 5.4, while the minimum yield of glucose concentration was observed on day nine of biodegradation at $\mathrm{pH} 6.18$. The study revealed that the growth of Aspergillus niger on rice husk increases its usefulness and that rice husk can through microbial degradation be converted to fermentable sugars and other useful product like alcohol. It also highlights the industrial potential of rice husks as possible substrates for cellulase enzyme production by Aspergillus niger which can eliminate agro-waste environmental pollution in Nigeria.
\end{abstract}

\author{
Volume 3 Issue 2 - 2018
}

\author{
Stephen Paul Edor,' Ocholi Paul Edogbanya, ${ }^{2}$ \\ Joseph Richard Kutshik ${ }^{3}$ \\ 'Department of Biochemistry, Ahmadu Bello University, Nigeria \\ ${ }^{2}$ Department of Biology, Ahmadu Bello University, Nigeria \\ ${ }^{3}$ Department of Biochemistry, University of Jos, Nigeria
}

Correspondence: Stephen Paul Edor, Department of Biochemistry, Ahmadu Bello University, Zaria, Nigeria, Tel +234(0)7036919688, Email edorsteve@gmail.com

Received:June 05, 2017 | Published: June II, 2018

Keywords: rice husk, Aspergillus niger, biodegradation, cellulase activity

\section{Introduction}

Cellulose containing wastes may be agricultural, urban or industrial in origin; for example sewage sludge might also be considered a source of cellulose. Since the cellulosic content provides the carbon source needed for methane production in anaerobic digestion of sludge. Cellulose which forms about $40-50 \%$ of plants composition is the most abundant organic matter on earth. ${ }^{1}$

Proper biotechnological utilization of these wastes in the environment will eliminate pollution and convert them into useful byproduct. $^{2}$

The recent trust in bioconversion of agricultural and industrial wastes to chemical feedstock has led to extensive studies on cellulolytic enzymes produced by fungi and bacteria. ${ }^{3}$ Cellulase production by various microorganism including Saccharomyces cerevisiae and Aspergillus niger in some agro waste (such as banana peel, millet, Guinea corn, maize straw and rice husk) has been reported. ${ }^{2,3}$

Rice husk an agricultural by-product of rice milling, is available in abundance in Nigeria and presently has no direct nutritional value, it is left to rot or used as fuel. An attempt at feeding it to poultry resulted in poor growth performance as a result of low nutritional quality, high fiber and lignin content. ${ }^{4}$

Biodegradation is the application of biological principle for the purpose of converting food stuff into more palatable nutritional or staple food; it has the potential to improve the nutritional value of fibrous agricultural by-product. ${ }^{5}$ Enzymatic hydrolysis of cellulose is carried out by enzyme which is highly specific. ${ }^{6}$ Aspergillus niger is worldwide in distribution and has been isolated from numerous habitat. ${ }^{7}$ Humans are continually exposed to Aspergillus niger spores and vegetative forms on foodstuffs and in air. The vast majority of Aspergillus niger strains especially those used in industrial fermentation have a history of safe use. ${ }^{8}$

Despite the worldwide and numerous utilization of natural cellulosic sources; there are still abundant quantities of cellulose containing raw materials and waste products that are not yet exploited or used efficiently. ${ }^{9}$

The problem in this respect is to develop processes that are economically profitable. Proper biotechnological utilization of these waste in the environment will eliminate pollution and convert them into useful by product. ${ }^{2}$

The focus of this research was to investigate economically viable means of utilizing agro-industrial waste such as risk husk using Aspergillus niger by solid state fermentation.

\section{Materials and methods}

Collection of sample: The rice husk was collected from a small rice milling industry in Katako, Jos, in Plateau State.

Micro-organism: Stock culture of Aspergillus niger was obtained from the Botany Department of the University of Jos, Nigeria.

Maintenance medium: Aspergillus niger was maintained on Potatoes dextrose agar (PDA) plates.

Inoculum preparation: The fungus was sub-cultured on PDA plates for seven days. Spores suspension was prepared in $2 \%(\mathrm{v} / \mathrm{v})$ of Tween 80 solution containing $2.52 \times 10^{6}$ spores $/ \mathrm{ml}$ counted with binocular using Haemocytometer as described by Caritas and Humphrey. ${ }^{10}$

\section{Substrate preparation for biodegradation:}

Solar dried rice husk $(10 \mathrm{~g})$ was dissolved in a $250 \mathrm{ml}$ conical flask with $100 \mathrm{ml}$ of distilled water as described by Caritas \& Humphrey ${ }^{10}$ Hydrolysate $(10 \mathrm{ml}$ each) was taken into five different $100 \mathrm{ml}$ conical flask, then $1 \mathrm{ml}$ of $2.52 \times 10^{6}$ spores suspension of Aspergillus niger was added aseptically to each conical flask and incubated at room temperature $\left(30^{\circ}\right)$

Samples were incubated for nine (9) days after which the reducing 
sugar was determine using Somogyi Nelson Method for the intervals of Days $0,2,5,7,8$, and 9 respectively.

\section{Test for cellulase activity of Aspergilus niger}

The cellulase activity of Aspergillus niger was determined using mineral salt medium (MSM) as described by Omojasola \& Jilani ${ }^{11}$ Composition of mineral salt medium (MSM) : $\mathrm{K}_{2} \mathrm{HPO}_{4}(1.8 \mathrm{~g}), \mathrm{NH}_{4} \mathrm{Cl}$ (4.0g), $\mathrm{MgSO}_{4} \cdot 7 \mathrm{H}_{2} \mathrm{O}(0.2 \mathrm{~g}), \mathrm{NaCl}(1.0 \mathrm{~g}), \mathrm{NaSO}_{4} .7 \mathrm{H} 2 \mathrm{O}(0.01 \mathrm{~g})$ and distilled water $(250 \mathrm{ml})$

The mineral salt medium ingredient were thoroughly mixed in a $500 \mathrm{ml}$ conical flask and $250 \mathrm{ml}$ of distilled water was added and swirled to mix and then $10 \mathrm{~g}$ of powered rice husk was added into conical flask and mixed properly. The mixture was then sterilized by autoclaving at $121^{\circ} \mathrm{C}$ for 15 minutes, cooled and poured into two test tubes (Test and Control). Isolate of Aspergillus niger was inoculated into the test tubes using wire loop and was plugged with cotton wool and wrapped with aluminum foil, then incubated at room temperature for two days and observed for turbidity. ${ }^{11}$

\section{Results}

During the experiment it was observed that there was a significant increase in the sugar content as the days increased and it reached a peak then declined (Table 1). Day five had the highest glucose yield (77.94\%) when compared with the control; while day nine had the lowest yield (11.03\%).

Table I Effect of incubation period on glucose concentration

\begin{tabular}{lll}
\hline $\begin{array}{l}\text { Duration of } \\
\text { biodegradation }\end{array}$ & $\begin{array}{l}\text { Glucose concentration } \\
(\mathbf{m g} / \mathbf{m l})\end{array}$ & $\begin{array}{l}\text { Percentage } \\
\text { increase }\end{array}$ \\
\hline Day Zero(Control) & $0.562 \pm 0.003^{\mathrm{a}}$ & - \\
Day two & $0.674 \pm 0.018^{\mathrm{a}}$ & 21.89 \\
Day five & $1.020 \pm 0.026^{\mathrm{c}}$ & 77.94 \\
Day seven & $0.752 \pm 0.002^{\mathrm{a}}$ & 33.63 \\
Day eight & $0.937 \pm 0.002^{\mathrm{b}}$ & 66.73 \\
Day Nine & $0.624 \pm 0.002^{\mathrm{a}}$ & 11.03 \\
\hline
\end{tabular}

Values are presented as Mean \pm standard deviation; Values with different superscript within a column are statistically different $(P<0.05)$

There was also a significant change in the $\mathrm{pH}$ from initial as the days of fermentation increased (Figure 1) (Table 2).

Table 2 Change in $\mathrm{pH}$ of rice husk obtained at various periods of biodegradation

\begin{tabular}{llll}
\hline $\begin{array}{l}\text { Duration of } \\
\text { biodegradation }\end{array}$ & Initial pH & Final pH & $\begin{array}{l}\text { \% Increase } \\
\text { in } \mathbf{~ H ~}\end{array}$ \\
\hline Day Zero(Control) & 4.5 & - & - \\
Day two & 4.5 & 5.3 & 17.78 \\
Day five & 4.5 & 5.4 & 18 \\
Day seven & 4.5 & 5.9 & 31.11 \\
Day eight & 4.5 & 6.1 & 35.56 \\
Day Nine & 4.5 & 6.18 & 37.33 \\
\hline
\end{tabular}

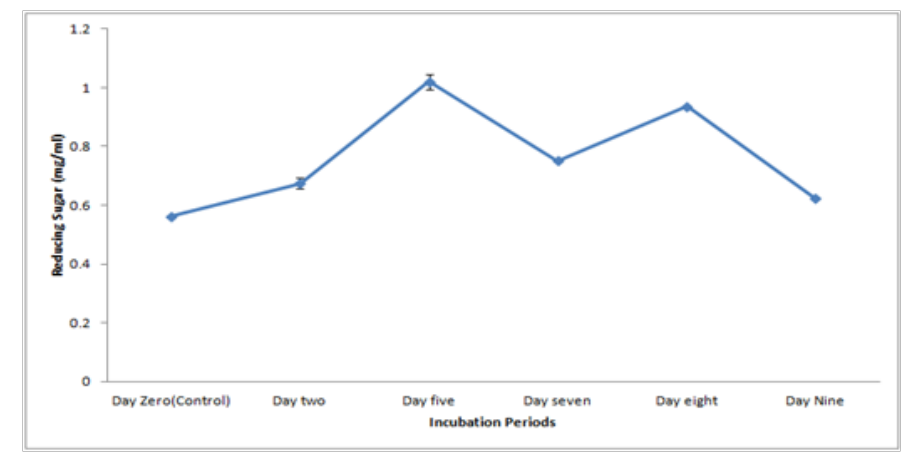

Figure I Effect of incubation period on glucose concentration.

\section{Discussion}

The gradual increase of the reducing sugar content from day zero (0) to day nine (9) of biodegradation is indicative of cellulase production by Aspergillus niger. This result agrees with previous studies that cellulase production by various microorganism including Saccharomyces cerevisiae and Aspergillus niger in some agro waste (like rice husk, banana peel, millet, guinea corn and maize straw) occurs. $^{3,2}$

The gradual increase in the glucose content of the biodegraded rice husk confirms that Cellulase (a complex multi-enzyme system) acts collectively to hydrolyze cellulose from agricultural wastes such as rice husk to produce simple glucose units. ${ }^{12}$

The maximum yield of glucose units on day five (5) of biodegradation was similar to the work of ${ }^{10}$ and ${ }^{13}$ which also gave a similar time course report of maximum glucose yield on day five (5) of fermentation with $A$. niger. This might be due to the availability of cellulose in the medium on day five, or the fact that the enzyme activity was at its maximum.

The decrease in glucose production below the maximum yield may be explained to be as a result of an inhibitory effect of the accumulated cellobiose and cellodextrins of low degree of polymerization to the growth medium. It might also be due to the specific binding of the enzymes with the substrates. ${ }^{14}$ Low glucose production below the maximum yield, as recorded in day nine (9) of biodegradation highlights sugar depletion from the substrates in the medium. ${ }^{15}$

\section{Conclusion}

In conclusion, this study revealed that rice husk, a major waste product of rice milling factories, can through microbial fermentation be converted to simple sugars and other useful products like alcohol. It also indicates the industrial potential of rice husk as possible substrate for Cellulase enzyme, production by Aspergillus niger which can also eliminate agro-wastes environmental pollution in Nigeria.

\section{Acknowledgments \\ None.}

\section{Conflict of interest}

Author declares no conflict of interest. 


\section{References}

1. Saranraj P, Stella D, Reetha D. Microbial Cellulases and Its Applictions International Journal of Biochemistry and Biotechnology Science. 2012;1:1-12.

2. Milala MA, Shugaba A, Gidado A, et al. Studies on the use of agricultural wastes for cellulase enzyme production by Aspergillus niger. Res J Agric Biol Sci. 2005;1(4):325-328

3. Baig MMV, Baig MLB, Baig MIA, et al. Saccharification of banana agro-waste by cellulolytic enzymes. African Journal of Biotechnology. 2004;3(9):447-450.

4. Aderolu AZ, Iyayi EA, Onilude AA, et al. Biodegraded rice husks in laying bird's diet: 1. Performance and egg quality parameters. Livestock Research for Rural Development. 2004;16(11).

5. Larry RB. Application of biotechnology to indigenous foods. Food Technology January. 1995;86-90.

6. Weiss N, Börjesson J, Pedersen LS, et al. Enzymatic lignocellulose hydrolysis: Improved cellulase productivity by insoluble solids recycling. Biotechnology for biofuels. 2013;6(1):5.

7. Anderson IC, Cairney JW. Diversity and ecology of soil fungal communities: increased understanding through the application of molecular techniques. Environ Microbiol. 2004;6(8):769-779.

8. Ruchi Sharma. Pathogenicity of Aspergillus niger in plants. Cibtech Journal of Microbiology. 2012;1(1):47-51.
9. Patagundi BI, Shivasaran CT, Kaliwal B. Isolation and characterization of cellulase producing bacteria from soil. International Journal of Current Microbiology and Applied Sciences. 2014;3(50):59-69.

10. Caritas UO, Humphrey CN. Effect of Acid Hydrolysis of Garcinia kola (bitter Kola) pulp waste on the production of CM-cellulase and $\beta$-glucosidase using Aspergillus niger. Afr J Biotechnol. 2006;5(10):819822 .

11. Omojasola PF, Jilani OP. Cellulase production by Trichoderma longi, Aspergillus niger and Saccharomyces cerevisae cultured on waste materials from orange. Pak J Biol Sci. 2008;11(20):2382-2388.

12. Singhvi MS, Chaudhari S, Gokhale DV. Lignocellulose processing: a current challenge. Rsc Advances. 2014;4(16):8271-8277.

13. Narasimha G, Sridevi A, Buddolla V, et al. Nutrient effects on production of cellulolytic enzymes by Aspergillus niger. African Journal of Biotechnology. 2006;5(5):472-476.

14. Wang XJ, JG Bai, YX Lian. Optimization of multienzyme production by two mixed strains in solid-state fermentation. Appl Microbiol Biotechnol. 2006;73(3):533-540.

15. O'Brien DJ, Craig JC. Ethanol production in a continuous fermentation/ membrane pervaporation system. Applied microbiology and biotechnology. 1996;44(6):699-704. 